\title{
Studies on some Trematode parasites of fresh water Fishes from Lucknow *
}

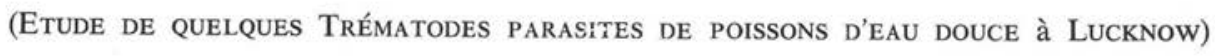

\author{
Par Vinod AGRAWAL **
}

\begin{abstract}
.
Two new species namely, Phyllodistomum cameroni n. sp. from Rita rita and Genarchopsis punctati n. sp. from Ophicephalus punctatus are described. In addition three redescriptions viz. Bucephalopsis garuai (Verma, 1936) from Pseudeutropius garua; Phyllodistomum tripathi (Motwani \& Srivastava, 1961) from Bagarius yarrelli and Pseudeutropius garua, and Astiotrema reniferum (Looss, 1898), Stoss., 1904 from Heteropneustes fossilis are given.
\end{abstract}

\section{Résumé}

Deux espèces nouvelles, Phyllodistomum cameroni n. sp. provenant de Rita rita, et Genarchopsis punctati n. sp. provenant d'Ophicephalus punctatus sont décrites. En outre, trois redescriptions de Bucephalopsis garuai (Verma, 1936) provenant de Pseudeutropius garua, de Phyllodistomum tripathi (Motwani et Srivastava, 1961) provenant de Bagaruis yarrelli et Pseudeutropuis garua, enfin d'Astiotrema reniferum (Looss, 1898) Stoss., 1904 provenant d'Heteropneustes fossilis sont données.

\section{FAMILY BUCEPHALIDAE Poche, 1907 BUCEPHALOPSIS GARUAI (Verma, 1936)}

(Pl. I, fig. 1-6)

A large number of specimens of this form were collected from the intestine of a fresh water fish, Pseudeutropius garua (Ham.) at Lucknow. Since there is a great variability in the arrangement of internal organs and considerable variations in the dimensions of the organs of the species, a redescription is given here for clarity. Lucknow.

* Part of thesis accepted for the degree of Doctor of Philosophy at the University of Lucknow,

** The work has been carried out under the direction of $\mathrm{D}^{\mathrm{r}} \mathrm{S}$. P. Gupta, Department of Zoology, University of Lucknow, Lucknow. The author is greatly indebted to him for his invaluable help and encouragment. 


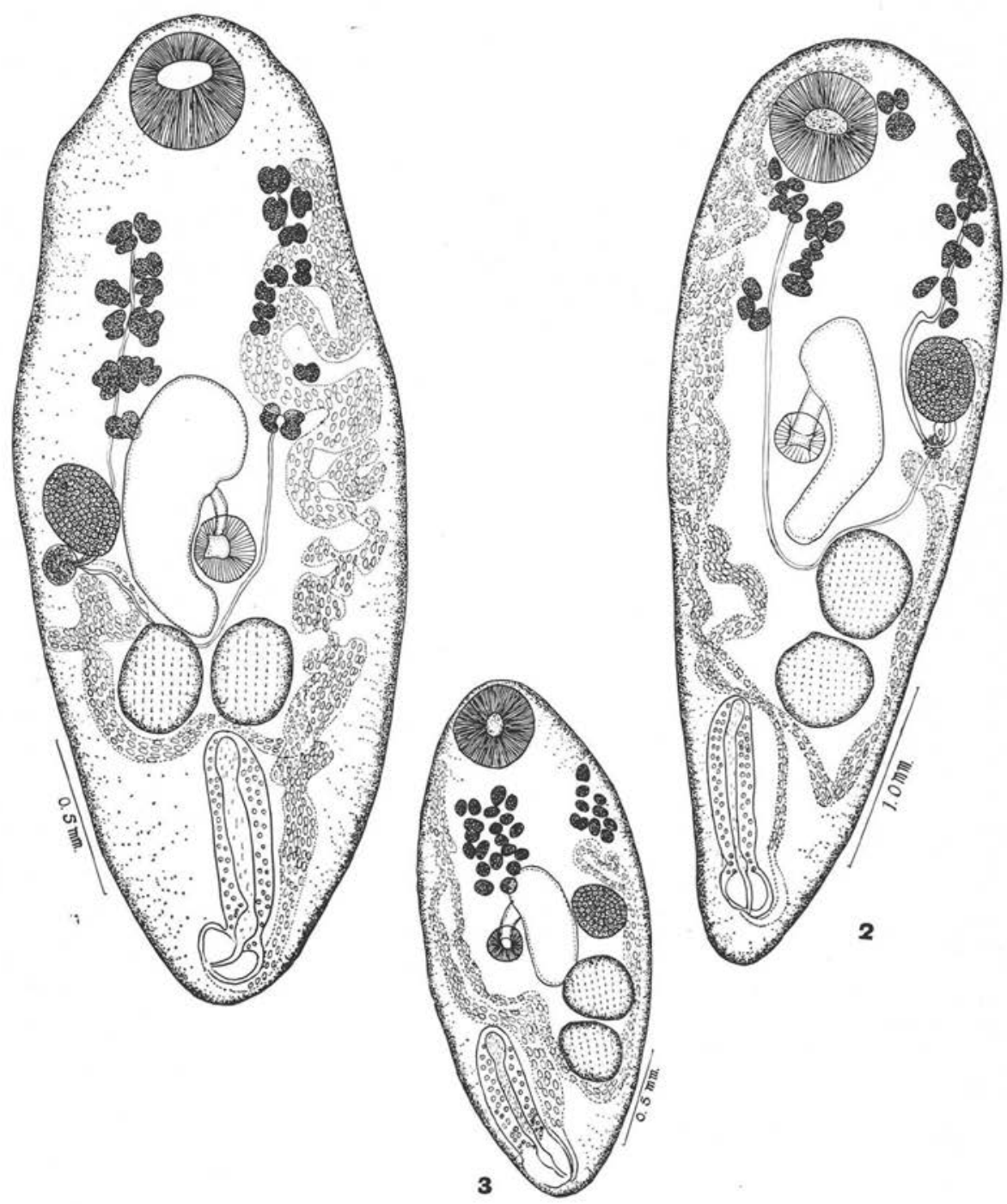

PL. I. Fig. 1-6: Bucephalopsis garuai (Verma, 1963) :

FIG. 1. - Vitellogènes bibolés. Vue ventrale Planche I, Fig. 1,2 et 3

PL. 2. - Circonvolutions utérines jusqu'à l'extrémité antérieure. Vue dorsale FIG. 3. - Testicule postérieur n'allant pas au-delà de la poche du cirre. Vue dorsale 

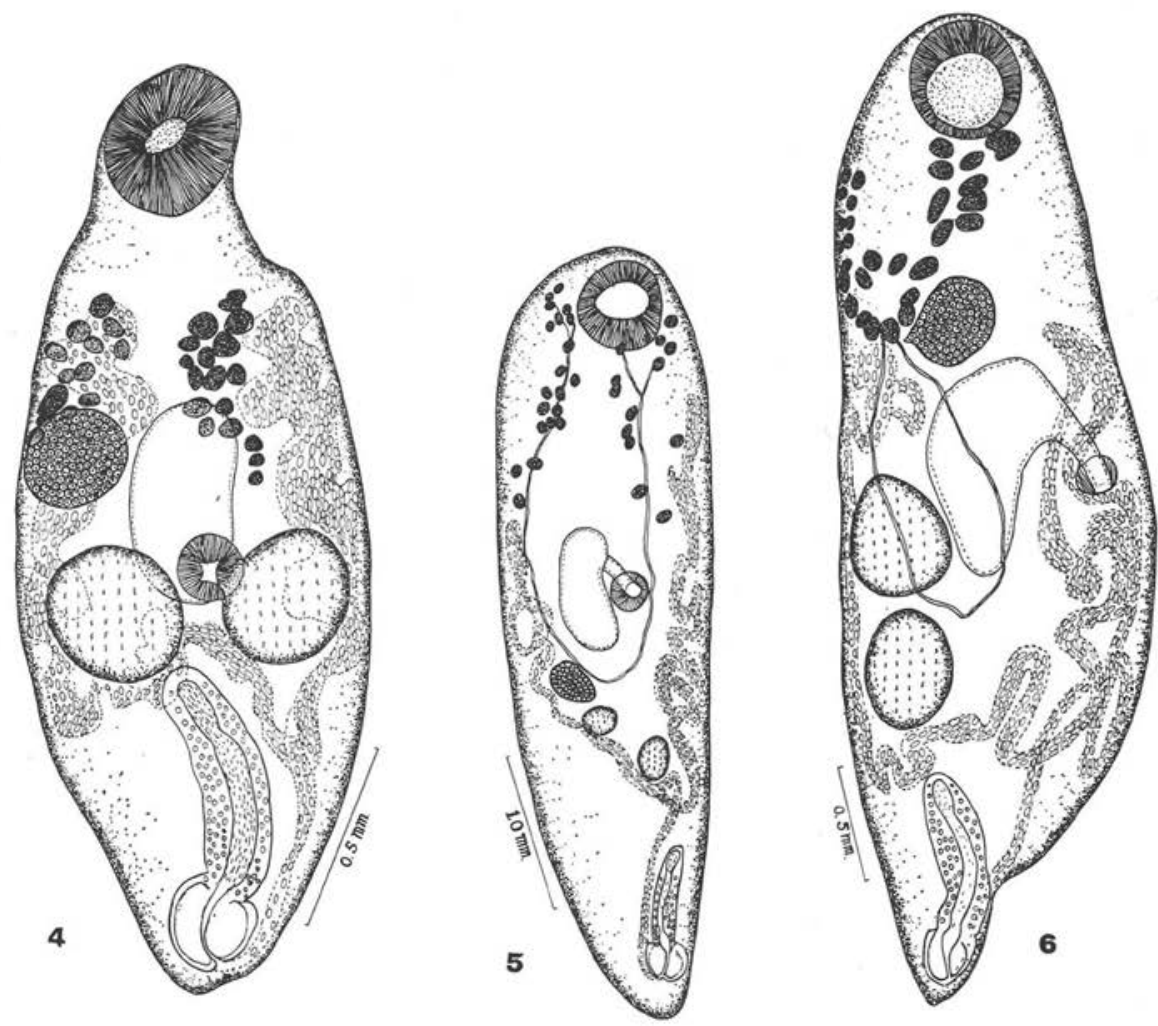

Planche I, Fig. 4,5 et 6

Fig. 4. - Pharynx intertesticulaire. Vue ventrale

Fig. 5. - Vittellogènes allant jusqu'à l'extrémité antérieure. Vue ventrale FIG. 6. - Ovaire en avant de l'intestin. Vue ventrale.

\section{Description :}

Body elongated, slender small to medium sized, aspinose, with its anterior part broad and posterior part narrow and rounded. It measures $2.45-5.40 \times 0.90-2.1 \mathrm{~mm}$. in size. Anterior sucker sub terminal, circular or oval, $0,36-0.73 \times 0.33-0.72 \mathrm{~mm}$. in size. Mouth in centre of body. Pharynx circular, equatorial, preequatorial or postequatorial, $0.15-0.25 \mathrm{~mm}$. from anterior extremity. Esophagus short and tubular. Intestine saccular, median or a little anterior to median plane. It measures $0.53-1.25 \times$ $0.25-0.52 \mathrm{~mm}$. in size at $0.88-1.85 \mathrm{~mm}$. from anterior extremity.

Excretory pore at posterior extremity. Excretory bladder 'Y' shaped.

Genital pore close to posterior extremity, subterminal and surrounded by feebly developed sphincter muscles. 
Testes globular or oval, entire, postovarian in same plane behind intestine on either side of pharynx or cirrus sac or on one side directly or obliquely tandem, overlapping or away from each other. The position and size of testes varies from specimen to specimen. Anterior testis lies from a little anterior to cirrus pouch upto middle region of intestine. It measures $0.20-0.60 \times 0.25-0.42 \mathrm{~mm}$. in size at $0.76-2.80 \mathrm{~mm}$. from hind end of body. Posterior testis lies from middle of cirrus pouch upto level of hind end of intestine. It measures $0.30-0.48 \times 0.25-0.50 \mathrm{~mm}$. in size at $0.73-1.75 \mathrm{~mm}$. from posterior extremity. Cirrus pouch large tubular extending from posterior end of body upto hind end of anterior testis ; size and position varies from specimen to specimen; length of cirrus sac varies from $1 / 6$ th to $1 / 3$ rd of body length, measuring $0.75-1.2 \times$ $0.20-0.30 \mathrm{~mm}$. in size. Vesicula seminalis oval and 0.51-1.15 $\times 0.06-0.12 \mathrm{~mm}$. in size. Pars prostatica large, globular, 0.08-0.21 $\times 0.05-0.10 \mathrm{~mm}$. in size, opening into a short ejaculatory duct, $0.11-0.30 \mathrm{~mm}$. in length. A large number of prostate gland cells fill up space in cirrus sac around vesicula seminalis and pars prostatica.

Ovary oval, entire, pretesticular situated on right or left side of intestine, anterior or posterior to it, measuring $0.23-0.46 \times 0.24-0.35 \mathrm{~mm}$. in size at $1.15-3.1 \mathrm{~mm}$. from posterior extremity. From its posterior side arises oviduct leading to oötype. Mehlis' gland cells surrounding oötype forming a compact oval mass at hind end of ovary and partly covering it. Vite!line glands rounded, follicular, entire or bilobed extending from anterior end of oral sucker or a little posterior to it upto middle of intestine or a little posterior to it. Follicles from 12-20 on each side of body. Two vitelline ducts on either side meet and form a yolk reservoir before opening at oötype. Uterus arises from oötype and extends anteriorly forming a number of coils upto anterior end of oral sucker, then turns towards posterior side to open at genital sinus. Eggs oval, non operculated, $0.021-0.042 \times 0.015-0.024 \mathrm{~mm}$. in size.

\section{Discussion :}

Verma (1936) described 5 species of the genus Bucephalopsis viz. B. fusiformis, B. garuai, B. magnum, B. confusus and B. minimus from the intestine of fresh water fishes at Allahabad. Bhalerao (1937) considered B. magnum, B. confusus and B. minimus as synonyms of $B$. garuai. The minor differences pointed out as existing between the species and the last three can be ascribed either to difference in age or individual variations. Nagaty (1937) considered B. garuai as a distinct species on the basis of bilobed or double nature of vitelline glands. Srivastava (1938) considered B. magnum as a valid species but maintains that $B$. confusus and $B$. minimus are synonymous to B. garuai. Gupta (1956) while redescribing B. magnum and B. karvei agreed with Nagaty in considering $B$. belonea as a synonym of $B$. karvei. The author is in agreement with Bhalerao (1937) in considering B. confusus, B. minimus and B. magnum to be synonym of $B$. garuai and does not agree with Nagaty, Srivastava and Gupta in considering B. garuai as distinct on the basis of bilobed or double nature of vitellaria as it is a variable character (depicted in figures). 
Host : Pseudeutropius garua (Ham.).

Location : Intestine.

Locality : Lucknow.

\section{FAMILY GORGODERIDAE Looss, 1901 PHYLLODISTOMUM CAMERONI n. sp.}

(Pl. II, fig. 1)

Only one specimen of this form was collected from the Urinary bladder of Rita rita (Ham.) obtained from fish market at Lucknow.

\section{Description :}

Body spatulate, $4.23 \mathrm{~mm}$. long and $2.23 \mathrm{~mm}$. wide just behind testicular region of body ; anterior part narrow and elongated, $1.8 \mathrm{~mm}$. long by $1.10 \mathrm{~mm}$. wide and posterior part expanded and nearly circular, $2.52 \mathrm{~mm}$. long by $2.23 \mathrm{~mm}$. wide. Oral sucker globular, terminal, $0.5 \mathrm{~mm}$. in diameter. Pharynx absent; esophagus tubular, $0.19 \times$ $0.08 \mathrm{~mm}$. in size. It bifurcates into two intestinal ceca, sinuous extending backwards marginally to terminate $0.25 \mathrm{~mm}$. from hind end. Ventral sucker circular, equal to oral sucker, $0.5 \mathrm{~mm}$. in diameter located $1.35 \mathrm{~mm}$. or nearly $1 / 3 \mathrm{rd}$ of body length from anterior extremity.

Excretory pore dorsal ; bladder long, tubular, extending as far as testes.

Genital pore median situated between intestinal bifurcation and ventral sucker at a distance of $0.95 \mathrm{~mm}$. from anterior extremity.

Testes lobed, intercaecal, subequal, postequatorial, symmetrical in broadest part of hind body and separated by uterine coils ; situated at a distance of $2.75 \mathrm{~mm}$. from anterior end and $0.28 \mathrm{~mm}$. behind ovary; right testis larger than left and $0.53 \times$ $0.40 \mathrm{~mm}$. in size, left testis $0.44 \times 0.42 \mathrm{~mm}$. in size. Cirrus sac absent. Vesicula seminalis free in parenchyma between intestinal bifurcation and ventral sucker, sac like and measures $0.15 \times 0.08 \mathrm{~mm}$. in size.

Ovary lobed, pretesticular, $0.42 \times 0.30 \mathrm{~mm}$. in size and situated on left side of vitelline gland at a distance of $0.2 \mathrm{~mm}$. from posterior margin of ventral sucker. From its right side arises oviduct leading to oötype. Vitelline glands consist of two divided follicles lying behind ventral sucker one on either side of oötype at a distance of $1.95 \mathrm{~mm}$. from anterior extremity; right vitelline gland $0.10 \times 0.028 \mathrm{~mm}$. and left $0.1 \times 0.029 \mathrm{~mm}$. in size. Ducts from two glands open separately at oötype. A large number of unicellular glands surround oötype. Uterus arises from hind end of oötype and runs backwards forming coils filling up nearly all space of body posterior to vitelline glands both intra and extra cecally also extending dorsal to ventral sucker to open at genital pore. Eggs oval, non operculated, 0.0391-0.0522 $\times 0.0194-0.0325 \mathrm{~mm}$. in size. 


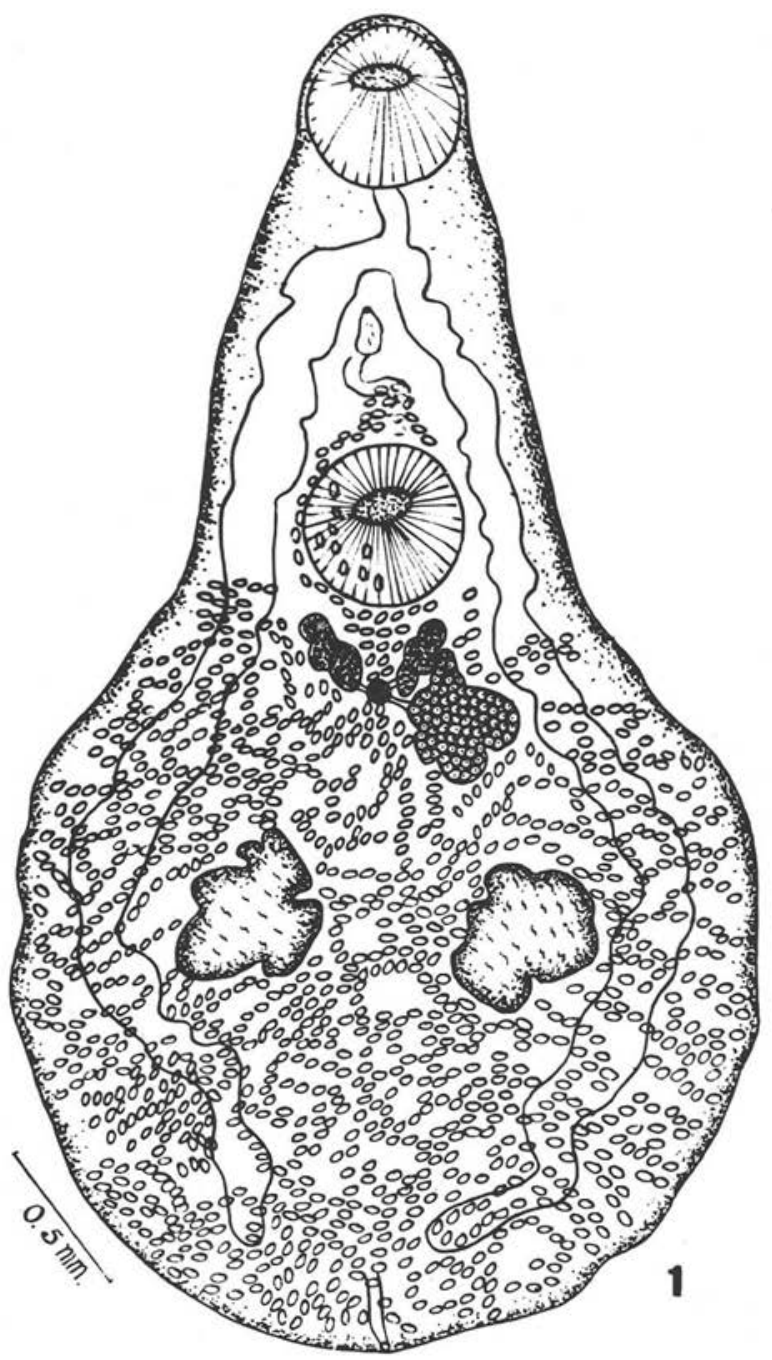

PL. II. - Fig. 1 : Phyllodistomum cameroni n. sp. Vue ventrale

Fig. 2-5: Phyllodistomum tripathi (Motwani et Srivastava, 1961) :

\section{Discussion :}

The new form belongs to the genus Phyllodistomum Braun, 1899. The following species of the genus Phyllodistomum have been described so far from fresh water fishes of India viz. P. lewisi Srivastava, 1958 ; P. vachius Dayal, 1949 ; P. loossi Kaw, 1950 ; P. singhiai Gupta, 1951 ; P. vittatusi Gupta, 1954 ; P. parorchim Jaiswal, 1957, P. india- 
num Jaiswal, 1957 ; P. chauhani Motwani \& Srivastava, 1961 ; P. tripathi Motwani \& Srivastava, 1961 and $P$. srivastavi Rai, 1964. The new form is distinct from all the above species of Phyllodistomum with the exception of $P$. loossi in having suckers of equal size. The new form differs from $P$. loossi in having posterior part disc like separated from much narrower anterior portion, in having symmetrical testes and in having ovary anterior to testes.

Accordingly it is regarded new with the specific name $P$. cameroni $\mathrm{n}$. sp. named after Dr. Thomas W. M. Cameron, Rtd. Director, Institute of Parasitology, Macdonald College, Mc Gill University, Montreal, Canada.

Host : Rita rita (Ham.).

Location : Intestine.

Locality: Lucknow.
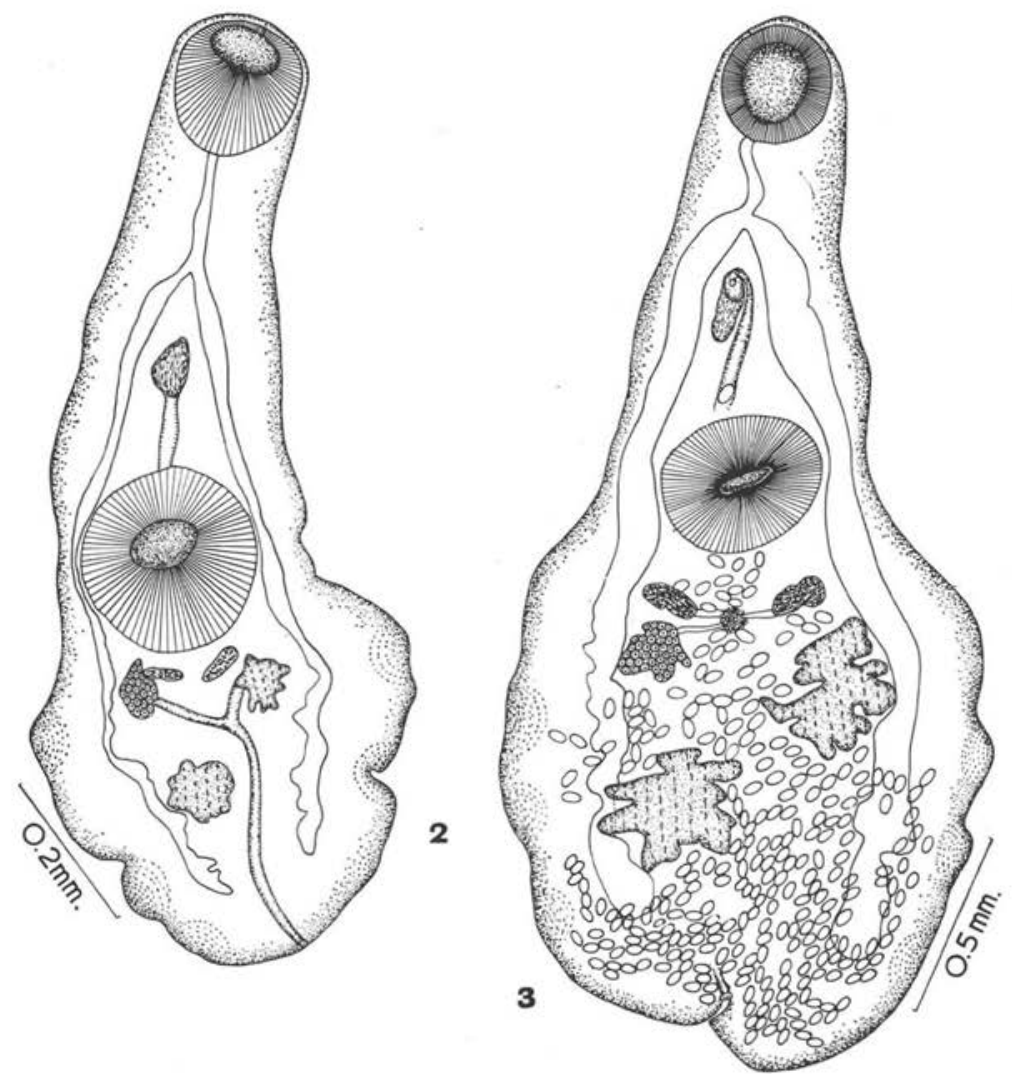

Fig. 2. - Vessie excrétrice. Vue dorsale.

Fig. 3. - Testicules en diagonale 


\title{
PHYLLODISTOMUM TRIPATHI (Motwani \& Srivastava, 1961)
}

\author{
(Pl. II, fig. 2-5)
}

A large number of specimens of this form were recovered from the intestine of a fresh water fish, Bagarius yarrellii (Ham.) and five immature specimens from the intestine of Pseudeutropius garua (Ham.) at Lucknow. As this species has not hither to been described adequately, it is therefore redescribed.
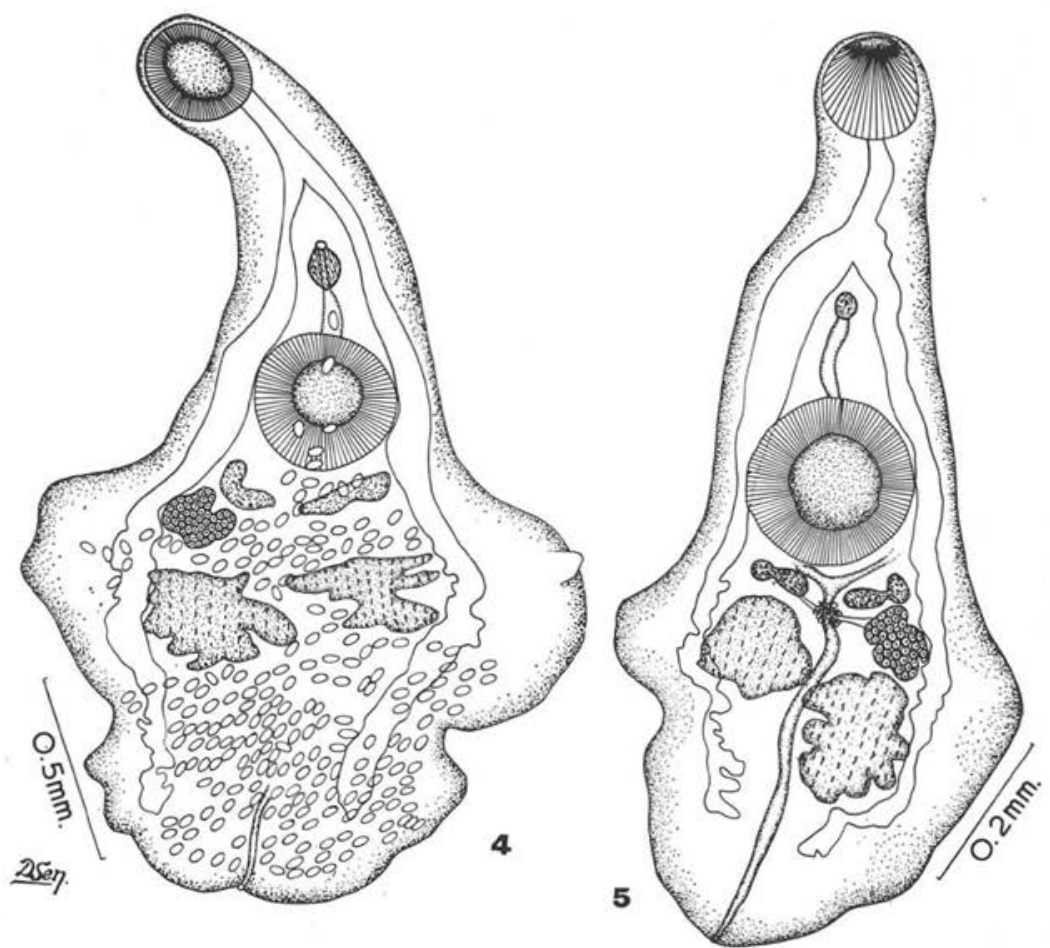

Fig. 4. - Testicules symétriques. Vue dorsale

Fig. 5. - Caecums intestinaux montrant des bords crénelés. Vue dorsale

\section{Description :}

Body dorsoventrally flattened, spatulate, $1.55-4.58 \mathrm{~mm}$. long and 0.74-2.02 $\mathrm{mm}$. wide at its broadest point in hind body. Forebody cylindrical, narrow, 0.90-2.7 $\times$ $0.53-0.80 \mathrm{~mm}$. in size and posterior portion broad and foliate, 0.69-2.0 $\times 0.74-2.02 \mathrm{~mm}$. 
in size. Three pairs of feebly developed semicircular puckerings present on lateral sides of hind body. Posterior end of body with well defined notch. Oral sucker terminal, oval, $0.19-0.50 \times 0.19-0.45 \mathrm{~mm}$. in size. Esophagus long, narrow, straight or curved, $0.11-0.45 \mathrm{~mm}$. in length, bifurcates into two intestinal ceca that terminate at $0.17-0.50 \mathrm{~mm}$. from hind end of body. Ceca broad with crinkled margins, and in some immature specimens very close together or apart from each other. Ventral sucker spherical, larger than oral sucker, $0.3-0.6 \mathrm{~mm}$. in diameter in anterior third of body at 0.67-2.0 $\mathrm{mm}$. from anterior extremity.

Excretory pore dorsally at posterior end of body. Excretory bladder tubular extending upto hind margin of ventral sucker then dividing into right and left branches.

Genital pore median, between intestinal bifurcation and ventral sucker at 0.43 $1.40 \mathrm{~mm}$. or nearly $1 / 4$ th from anterior extremity.

Testes deeply lobed, subequal, intercaecal, postequatorial, either close to posterior extremity or quite anterior to it, diagonal or symmetrical in broadest part of hind body well separated by uterine coils. Right testis at level of ovary but not in close proximity, $0.20-0.48 \times 0.20-0.60 \mathrm{~mm}$. in size at $0.30-1.12 \mathrm{~mm}$. from hind end. Left testis slightly larger than right located near termination of ceca or slightly anterior to it, $0.25-0.55 \times$ $0.20-0.50 \mathrm{~mm}$. in size at $0.15-0.90 \mathrm{~mm}$. from hind end. Cirrus sac absent. Vesicula seminalis saccular $0.08-0.25 \times 0.03-0.13 \mathrm{~mm}$. in size.

Ovary submedian, pretesticular and consists of 4-5 lobes, situated just behind left vitelline gland, $0.10-0.25 \times 0.09-0.25 \mathrm{~mm}$. in size at $1.06-2.8 \mathrm{~mm}$. from anterior extremity. Vitelline glands two, bilobed masses lying asymmetrically on both sides of body just behind ventral sucker close infront of ovary; right vitelline gland measures $0.03-0.12 \times 0.11-0.31 \mathrm{~mm}$. in size and left vitelline gland, $0.03-0.10 \times 0.11-0.32 \mathrm{~mm}$. in size. Two vitelline ducts run transversely and unite to form a common yolk reservoir from where a median vitelline duct originates and joins Mehlis' gland. Uterus arises anteriorly from oötype, then bends ventrally and subsequently filling posteriorly hind body inter and extracaecally. Anteriorly it runs dorsal to ventral sucker to open at genital pore. Eggs oval, non operculated, 0.0512-0.0752 $\times 0.0259-0.0492 \mathrm{~mm}$. in size.

\section{Discussion :}

The present form belongs to Phyllodistomum sp. Bhalerao, 1937 and $P$. tripathi Motwani \& Srivastava, 1961 but however differs from both of them, in the shape and position of testes and ovary, in having a well defined posterior notch and in the bilobed nature of vitellaria. These differences are considered variations within the species.

Hosts : Bagarius yarrelli (Ham.) \& Pseudeutropius garua (Ham).

Location : Urinary bladder.

Locality : Lucknow. 


\title{
FAMILY PLAGIORCHIIDAE Luhe, 1901, emend. Ward, 1917 ASTIOTREMA RENIFERUM (Looss, 1898) Stossich, 1904
}

\author{
(Pl. III, fig. 1)
}

Only one specimen of this form was collected from the intestine of a fresh water fish, Heteropneustes fossilis (Bloch.) at Lucknow.

\section{Description :}

Body elongated with rounded extremities, $2.54 \times 0.452 \mathrm{~mm}$. in size. Cuticle covered with small backwardly directed spines arranged in transverse rows. Spines become progressively denser on anterior surface; spines of each row alternating with preceeding and succeeding rows. Oral sucker terminal, subspherical, $0.14 \times 0.15 \mathrm{~mm}$. in size. Prepharynx absent ; pharynx large, spherical, $0.1 \mathrm{~mm}$. in diameter ; esophagus long, tubular, $0.28 \mathrm{~mm}$. in length, bifurcating into two intestinal ceca reaching short of posterior extremity. Ventral sucker oval, larger than oral sucker, $0.16-0.19 \mathrm{~mm}$. in size at $0.65 \mathrm{~mm}$. or about $1 / 4$ th of body length from anterior extremity.

Genital pore submedian, lying infront of ventral sucker at $0.63 \mathrm{~mm}$. from anterior extremity.

Excretory pore at hind end of body. Excretory bladder Y-shaped, main stem passes in between two testes in form of a sigmoid curve divided into two short arms between ovary and anterior testis.

Testes entire, oval lying obliquely one behind other in posterior half of body just behind equator. Anterior testis, $0.18 \times 0.16 \mathrm{~mm}$. in size at $1.29 \mathrm{~mm}$. from anterior extremity. Posterior testis slightly larger than anterior testis, $0.17 \times 0.19 \mathrm{~mm}$. in size at $0.724 \mathrm{~mm}$. from hind end of body. Cirrus sac claviform, elongated reaching upto ovary, $0.94 \times 0.09 \mathrm{~mm}$. in size. Vesicula seminalis large occupies a greater portion of cirrus sac, $0.45 \times 0.09 \mathrm{~mm}$. in size. Pars prostatica long, tubular, $0.14 \times 0.02 \mathrm{~mm}$. in size, continues forward as an ejaculatory duct, $0.27 \mathrm{~mm}$. in length, opening at genital pore. Cirrus muscular and non spiny.

Ovary entire, spherical, preequatorial, $0.08 \mathrm{~mm}$. in diameter at $1.1 \mathrm{~mm}$. from anterior extremity. Oviduct arises from hind end of ovary opening at oötype. Receptaculum seminis slightly larger than ovary and its left side, $0.085 \mathrm{~mm}$. in diameter. Vitellaria small, follicular, mainly lateral covering intestinal ceca extending from hind margin of ventral sucker upto middle region of hind testis. Uterus arises from oötype and runs posteriorly in a sinuous course towards posterior end, passes anteriorly to left of cirrus sac opening at genital pore. Eggs oval, non operculated, $0.0245-0.0355 \times$ 0.0112-0.0195 mm. in size.

\section{Discussion :}

The present form belongs to A. reniferum (Looss, 1898), Stoss, 1904 which has not previously been recorded from a fresch water fish, Heteropneustes fossilis. The 
PL. III. - Fig. 1: Astiotrema reniferum (Loos, 1899) Stoss. 1904. Vue dorsale

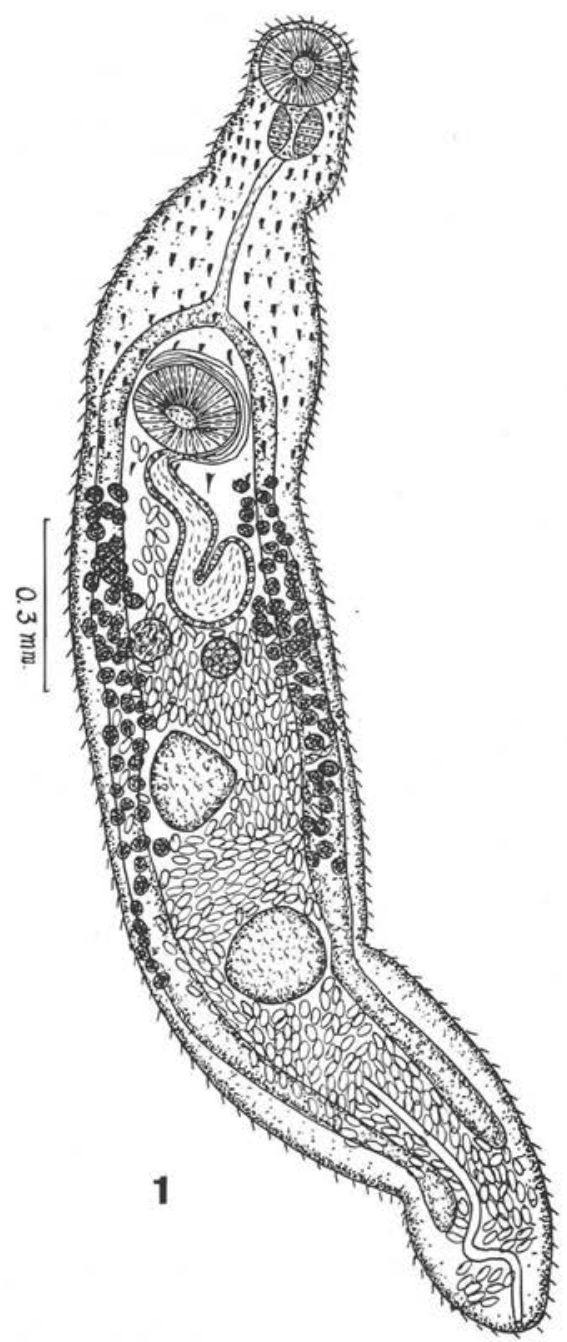

present form differs from other descriptions of $A$. reniferum in the possession of spines on the body wall, in the absence of prepharynx and in having vesicula seminalis $\mathrm{S}$ shaped. These differences are considered as variations within the species.

Location : Intestine.

Locality : Lucknow.

Host: Heteropneustes fossilis (Bloch.). 


\section{FAMILY HEMIURIDAE Luhe, 1901}

\section{GENARCHOPSIS PUNCTATI n. sp.}

(Pl. IV, fig. 1-5)

A large number of specimens of this form were collected from the stomach of Ophicephalus punctatus (Bloch.) obtained from fish market at Lucknow.
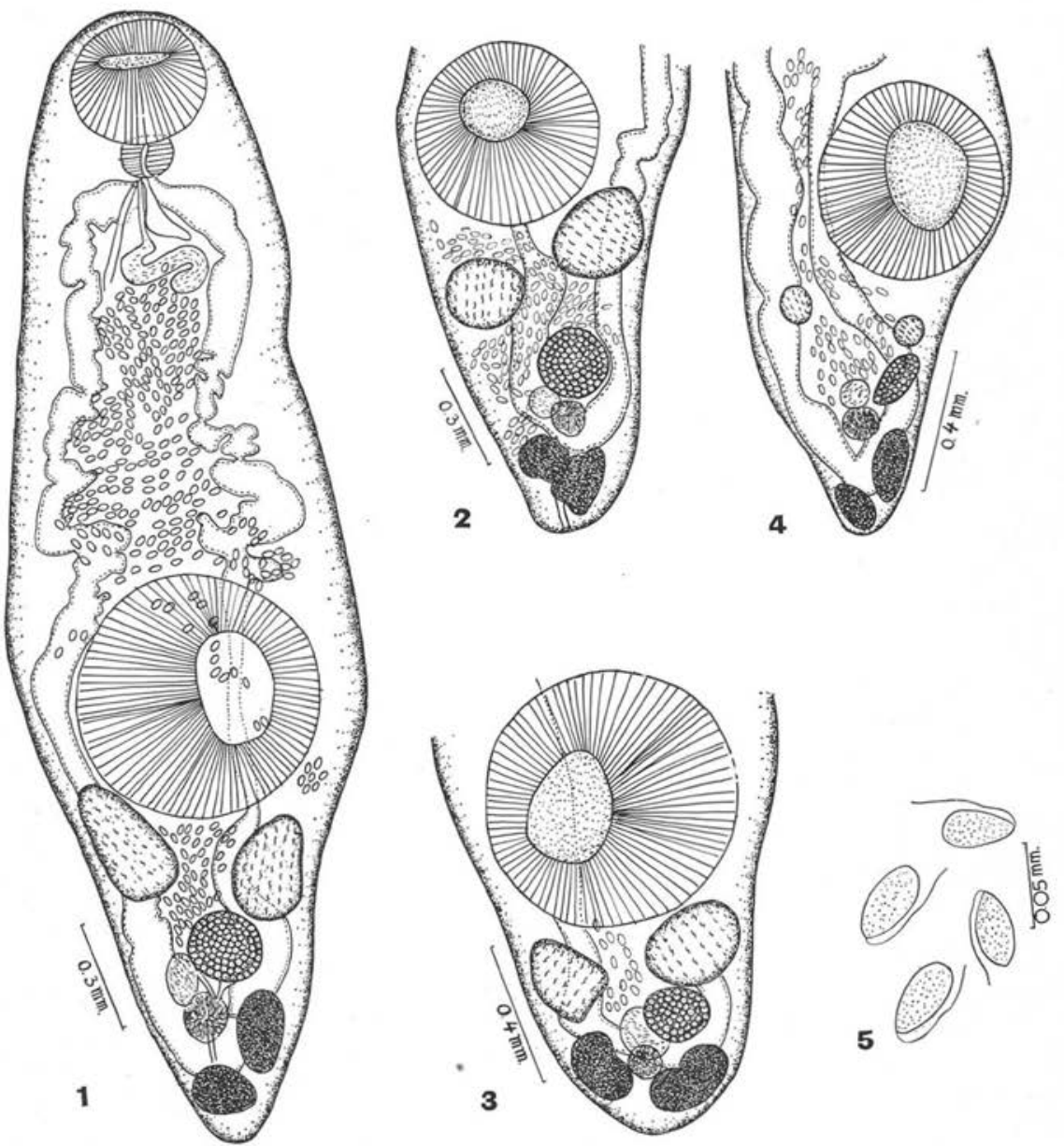

Fig. 1. - Vue ventrale

FIG. 2. - Vitellogènes lobès. Vue dorsale

Fig. 3. - Vitellogènes symétriques et ovaire proche des testicules. Vue dorsale Fig. 4. - Ovaire plus grand que les testicules. Vue dorsale

Fig. 5. - Eufs vus au fort grossissement 


\section{Description :}

Body fusiform with rounded extremities, 1.3-3.33 $\times 0.68-1.02 \mathrm{~mm}$. in size. Oral sucker subterminal, oval, $0.22-0.45 \times 0.27-0.46 \mathrm{~mm}$. in size. Prepharynx absent ; pharynx well developed, $0.05-0.12 \times 0.06-0.16 \mathrm{~mm}$. in size ; esophagus absent ; esophageal pouch arises from junction of pharynx and intestinal bifurcation, $0.12-0.22 \times$ 0.06-0.07 $\mathrm{mm}$. in size. Intestinal ceca crenated in outline, run in a wavy course to hind end of body and united together in vitellaria region. Ventral sucker larger than oral sucker, spherical, equatorial or postequatorial, $0.47-0.74 \mathrm{~mm}$. in diameter at 0.82-1.83 mm. from anterior extremity.

Genital pore median, close behind pharynx at a distance of $0.47-0.57 \mathrm{~mm}$. from anterior extremity.

Excretory pore dorsally at posterior end of body. Excretory bladder Y-shaped with an unbranched median stem dividing into two cornua extending upto ventral sucker uniting dorsal to pharynx.

Testes oval, postacetabular, subequal, entire, caecal and somewhat symmetrical or oblique in position. Left testis, $0.13-0.31 \times 0.10-0.26 \mathrm{~mm}$. in size and lies slightly nearer ventral sucker than right testis which measures $0.10-0.24 \times 0.09-0.24 \mathrm{~mm}$. in size. Cirrus sac absent. Vesicula seminalis elongated, S-shaped or somewhat winding in a coiled tube filled with sperms lying free in parenchyma far anterior to acetabulum and close to intestinal bifurcation. It measures $0.40-0.55 \times 0.05-0.06 \mathrm{~mm}$. in size. Pars prostatica tubular, $0.06-0.1 \mathrm{~mm}$. long enclosed in a thin walled sac surrounded by a large number of prostate gland cells. Ejaculatory duct, 0.05-0.06 mm. long opening in terminal part of uterus.

Ovary oval, postacetabular, entire, larger or smaller than testes, either close or away behind right testis. It measures $0.13-0.20 \times 0.12-0.22 \mathrm{~mm}$. in size at 0.25 $0.47 \mathrm{~mm}$. from hind end of body. Oviduct arises from right side of ovary and opens at oötype. Receptaculum seminis well developed, oval, lying postero dorsal to ovary, $0.06-0.15 \times 0.13-0.15 \mathrm{~mm}$. in size. Vitellaria consists of two large compact or lobed masses lying symmetrically or obliquely tandem in posterior region of body. Right vitelline gland measures, $0.17-0.23 \times 0.09-0.15 \mathrm{~mm}$. in size while left vitelline gland measures $0.13-0.23 \times 0.12-0.18 \mathrm{~mm}$. in size. Vitelline ducts arise from each vitelline gland and the two unite each other before opening at oötype. It lies just behind ovary and partly overlapped by it, $0.06-0.14 \times 0.11-0.15 \mathrm{~mm}$. in size. Uterus arises from dorsal side of oötype and forms closely packed transversely coils occupying mostly preacetabular area. The coils of the uterus are mainly internal and external to ceca. The terminal part of uterus receives ejaculatory duct forming hermaphrodite duct which opens at genital pore. Eggs oval with a polar filament at one end, 0.035-0.06 mm. in length. Eggs measures $0.04-0.05 \times 0.02-0.025 \mathrm{~mm}$. in size.

\section{Discussion :}

Srivastava (1933) considered that the genus Genarchopsis Ozaki, 1925 is identical and synonymous with the genus Progonus Looss, 1899. In the same year he created 
another genus Ophiocorchis with the type species $O$. lobatum under the subfamily Derogenetinae of the family Hemiuridae Luhe, 1901. He distinguished the genus Ophiocorchis from Progonus in the possession of a well developed globular parsprostatica, a large and highly muscular metraterm, a protrusible ductus hermaphroditicus and the oesophageal pouch. Yamaguti (1958) considered the genera Progonus Looss, 1899, Genarches Looss, 1902 and Ophiocorchis Srivastava, 1933 as a synonym of Genarchopsis Ozaki, 1925. The author is in agreement with Yamaguti as the characters separating the genus Ophiocorchis from Progonus are variable.

The new form is referred to the genus Genarchopsis Ozaki, 1925 of which seven species are known from fresh water fishes of India. The new form differs from all the known forms of the genus in the possession of a well developed receptaculum seminis and in having genital pore close behind the pharynx. The new form resembles G. lobatum (syn. Ophiocorchis lobatum); G. singularis (syn. O. singularis) and G. faruquis (syn. O. faruquis (syn. O. faruquis) in the possession of an oesophageal pouch. The new form differs from $G$. lobatum and $G$. singularis in having testes symmetrical instead of one behind the other. Further the new form differs from G. lobatum in having entire or slightly lobed vitellaria instead of lobed glands and from $G$. singularis in the non extension of uterine coils upto hind end of vitellaria. The new form bears a very close resemblance to $G$. faruquis but differs from it in not having Mehlis' gland complex anterior to ovary. These differences are sufficient to create a new species $G$. punctati n. sp.

Host: Ophicephalus punctatus (Bloch.).

Location: Stomach.

Locality : Lucknow.

KEY TO THE SPECIES OF THE GENUS Genarchopsis OZAKI, 1925

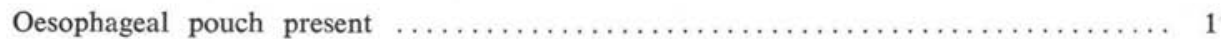

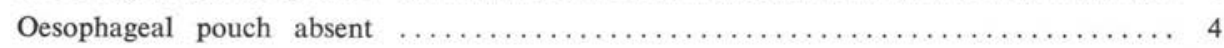

1. Receptaculum seminis present $\ldots \ldots \ldots \ldots \ldots \ldots \ldots \ldots \ldots \ldots \ldots \ldots \ldots \ldots$. punctati sp. nov.

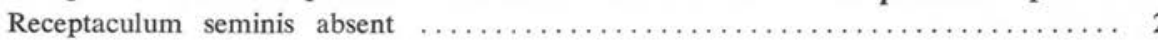

2. Genital pore on the ventral side of the left intestinal caecum near its bifurcation

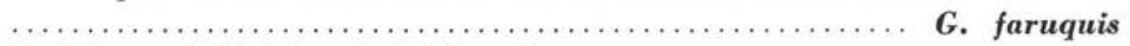

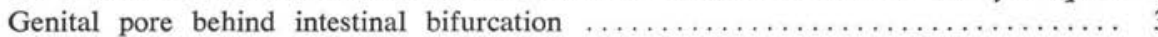

3. Vitelline glands lobed and uterine coils do not extend in the region of vitellaria

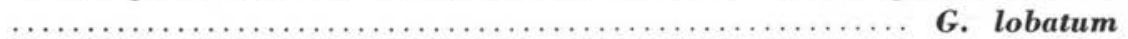

Vitelline glands compact and uterine coils extend between the vitellaria .........

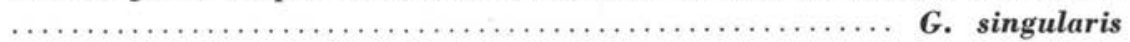

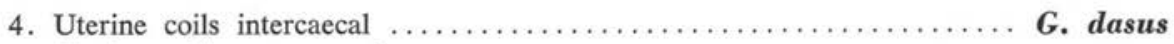

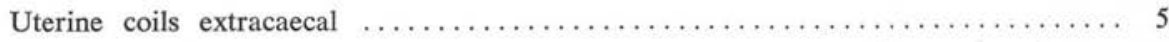

5. Genital pore intercaecal $\ldots \ldots \ldots \ldots \ldots \ldots \ldots \ldots \ldots \ldots \ldots \ldots \ldots \ldots \ldots \ldots$ G. ovocaudatum

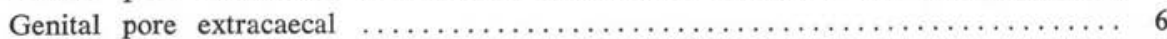


6. Genital pore in level with pharynx; vitellaria compact $\ldots \ldots \ldots \ldots$ G. piscicola Genital pore on the left side of oral sucker ; vitellaria lobed ...... G. indicus

\section{Bibliographie}

Bhalerao (G. D.), 1937. - Studies on the Helminths of India. Trematoda IV. Jour. Helminth., 15 : 97-124.

GuPTA (S. P.), 1956. - A redescription of Bucephalopsis magnum (Verma, 1936), Srivastava, 1938 and Bucephalopsis karvei Bhalerao, 1937. Ind. Jour. Helminth., 8: 112-121.

Nagaty (H. F.), 1937. - Trematodes of fishes from the Red Sea. Part. I. Studies on the family Bucephalidae Poche, 1907. Faculty of Medicine, Egyptian University., $12: 172$.

SRIVAStava (H. D.), 1933. - On new trematodes of frogs and fishes of the United Provinces, India. Part. I. Distomes of the family Hemiuridae from North Indian fishes and frogs with a systematic discussion on the family Halipegidae and the genera Vitellotrema Guberlet and Genarchopsis Ozaki. Bull. Acad. Sci. Allahabad. 3 (1): 41-60.

Srivastava (H. D.), 1938. - Studies on the Gasterostomatous parasites of Indian food fishes. Ind. Jour. Vet. Sci. \& Ani. Husb., 18 (4) : 312-340.

Verma (S. C.), 1936. - Studies on the family Bucephalidae (Gasterostomata). Part. I. Descriptions new forms from Indian fresh water fishes. Proc. Nat. Acad. Sci., 6: 66-89.

Yamaguti (S.), 1958. - Systema Helminthum. Interscience Publishers, New York, London, Vol. 1 \& 2: 1-979.

(Department of Zoology, University of Lucknow, Lucknow, U.P. India) 